\title{
THE CRUSTAL STRUCTURE BENEATH THE VITÓRIA-TRINDADE RIDGE
}

\author{
ROBERTO FAINSTEIN* and H. C. CLARK*
}

\begin{abstract}
From the analyses of bathymetric and seismic profiles, and the correspondent free-air gravity anomalies, two-dimensional crustal models were derived for the eastern part of the Vitória-Trindade ridge. The models account for the regional flexure of the oceanic lithosphere under the action of the load represented by the ridge.
\end{abstract}

RESUMO Da análise de perfis batimétricos e sísmicos e das correspondentes anomalias gravimétricas de "ar-livre", modelos de estrutura da crosta oceânica foram obtidos para o flanco leste da cadeia de montanhas oceânicas de Vitória-Trindade. Para a obtenção dos modelos bidimensionais levou-se em consideração a flexão regional da litosfera oceânica sob a ação da carga representada pela cadeia de montanhas.

INTRODUCTION The Vitória-Trindade ridge (Fig. 1) is a nearly linear chain of seamounts, guyots and oceanic islands, trending approximately east-west between the $20^{\circ} \mathrm{S}$ and $21^{\circ} \mathrm{S}$ parallels. This narrow aseismic ridge has an extension of about $1200 \mathrm{~km}$ and an average width of about $80 \mathrm{~km}$. The ridge was formed, most probably, by magmatic activity along a fracture zone (Almeida, 1965; Ponte and Asmus, 1975). The eastern boundary of the ridge is formed by the Trindade and Martim $\mathrm{Vaz}$ islands. At the western side the ridge intersects the continental margin forming a basement high known as the Vitória arch (Ponte and Asmus, 1975).

Chains of seamounts and volcanic islands like the Vitória-Trindade ridge act as a supracrustal load on the oceanic lithosphere causing its regional bending. Well known examples include the Hawaiian ridge - Emperor seamount chain (Walcott, 1970b; Watts and Cochran, 1974; Lliboutry, 1974) in the Pacific, the Great Meteor seamount chain (Watts et. al., 1975) in the North Atlantic, and the Quito ridge(Kogan, 1976) in the South Atlantic.

This paper examines two geophysical profiles which cross the Vitoria-Trindade ridge in a direction almost perpendicular to its strike. The ridge acts as a line load over the oceanic lithosphere. The load inferred from the bathymetric profiles is used to calculate deflections of the lithosphere assuming different values of lithosphere rigidity. Then, the crustal models created in this fashion are inverted and their gravity effects matched to the observed free-air anomaly. The best model then determines the appropriate lithosphere deflection and rigidity, and the model itself represents the crustal structure under the ridge.

VOLCANICS Apparently volcanic activity along a deep sea oceanic fracture zone formed the chain. But, how did this volcanic activity take place? There is no doubt that a fracture zone represents a zone of weakness that may be reactivated from time to time. What triggers the volcanism nevertheless remains unclear.

* Rice University - Department of Geology - Houston, Texas 77001 USA 
It is interesting to note that radiometric dating for the Trindade and Martim $\mathrm{Vaz}$ islands give very different values. Trindade is a volcanic episode about 2 my old, while Martim Vaz is apparently much older (Cordani, 1970). On the other hand basaltic rocks from the Abrolhos islands (Fig. 1) give ages between 52 and 42 my old (Cordani, 1970). It seems therefore that there is no age trend governing these volcanic eruptions, precluding consequently the idea that the chain represents traces of a hot-spot.

THEORY OF THE METHOD For a simple model of bending (Fig. 2), we assume a purely elastic lithosphere overlying a weaker fluid, the asthenosphere. With the assumption of two-dimensionality, the vertical deflection due to the point load, in the absence of external horizontal forces, is described by the equation: (Nadai, 1968; Landau and Lipschitz, 1969)

$E I \frac{d^{4} y}{d x^{4}}+\left(\rho_{m}-\rho_{c}\right) g y=P \cdot \delta(x)$

where $E$ is the Young's modulus; $I$ is the moment of inertia; $\rho_{m}$ is the density of the substratum; $\rho_{c}$ is the density of the load; $g$ is the gravity; $y$ is the amount of vertical deflection; $P$ is the strength of the load; $\delta(x)$ is the Dirac delta function and $x$ is the distance along the profile.

The expression:

$D=E I=\frac{E T^{3}}{12\left(1-\nu^{2}\right)}$

is known as the flexural rigidity, and represents a measure of the resistance given by the lithosphere to bending. Here, $T$ represents the thickness of the lithosphere, and $v$ is the Poisson's ratio, commonly assumed to equal to .25 for an elastic lithosphere.

The solution of equation (1) may be obtained by the Fourier transform method (Appendix) and is:

$y(x)=\frac{P}{2 \alpha\left(\rho_{m}-\rho_{c}\right) g} \cdot\left(\cos \frac{|x|}{\alpha}+\sin \frac{|x|}{\alpha}\right) \exp \frac{-|x|}{\alpha}$

where

$\alpha=\left\{\frac{4 D}{\left(\rho_{m}-\rho_{c}\right) g}\right\}^{1 / 4}$

is referred to by some investigators as the "flexural parameter" (Walcott, 1970a; Le Pichon et al., 1973). It represents a measure of the amplitude and wavelength of the deflection. 
For the computation of the vertical gravitational attraction of the two-dimensional models, we used the method of Talwani et al. (1959):

$\Delta g=2 G \rho \quad \sum_{i=1}^{n} \quad Z_{\mathrm{i}}$

where $\Delta g$ is the vertical gravitational attraction, $G$ is the universal gravitational constant, $\rho$ is the density of the body and

$$
\begin{aligned}
& Z_{\mathrm{i}}=a_{i} \sin \phi_{i} \cos \phi_{i}\left[\theta_{i}-\theta_{i+1}+\tan \phi_{i} \cdot \ln \frac{\cos \theta_{i}\left(\tan \theta_{i}-\tan \phi_{i}\right)}{\cos \theta_{i+1}\left(\tan \theta_{i+1}-\tan \phi_{i+1}\right)}\right] \\
& \theta_{i}=\tan ^{-1}\left(\frac{z_{i}}{x_{i}}\right) \\
& \phi_{i}=\tan ^{-1}\left(\frac{z_{i+1}-z_{i}}{x_{i+1}-x_{i}}\right) \\
& a_{i}=x_{i+1}+z_{i+1} \frac{x_{i+1}-x_{i}}{z_{i}-z_{i+1}}
\end{aligned}
$$

where $x_{i}$ is the $x$ coordinate for the ith point of the body, and $z_{i}$ is the $z$ coordinate (positive downwards) for the ith point of the body (Fig. 3).

ANALYSIS OF THE GEOPHYSICAL PROFILES Among the few geophysical profiles at the Vitória-Trindade ridge, two were suitable for our study. Profiles AA' (R/V Vema 17-12) and BB' (R/V Vema 24-13) cross the ridge (Fig. 1) in such a way that our fundamental assumptions hold. A free-air anomaly map can be produced with the available information in the region, but synthetic profiles did not develop the detail appropriate for our study.

Profile AA' was taken across Davis Bank, a flat-top guyot (Fig. 4) which most probably was entirely eroded by the sea (Almeida, 1965). Profile BB' was obtained over the western flank of the Columbia seamount (Fig. 4 e 5).

The profile across Davis Bank shows a prominent free-air gravity anomaly over the guyot, with amplitude up to 240 milligals, over an extension of $60 \mathrm{~km}$. Two sidelobes with anomalies of about -60 mgals and wavelength of about $120 \mathrm{~km}$ clearly show that a mass deficiency exists at each side of the guyot (Fig. 4). The profile across the Columbia seamount is less conclusive because the seamount, being a smaller load, produces a smaller effect. The gravity profile is subdued at one side of the seamount, and the free-air anomaly reaches an amplitude of 130 milligals over an horizontal extent of about $50 \mathrm{~km}$. The guyot (profile AA') is as shallow as $60 \mathrm{~m}$ as opposed to a depth of about $4 \mathrm{~km}$ at the adjacent ocean basin, while the seamount has a depth of about $850 \mathrm{~m}$ with its adjacent ocean basin of about $4.4 \mathrm{~km}$. 


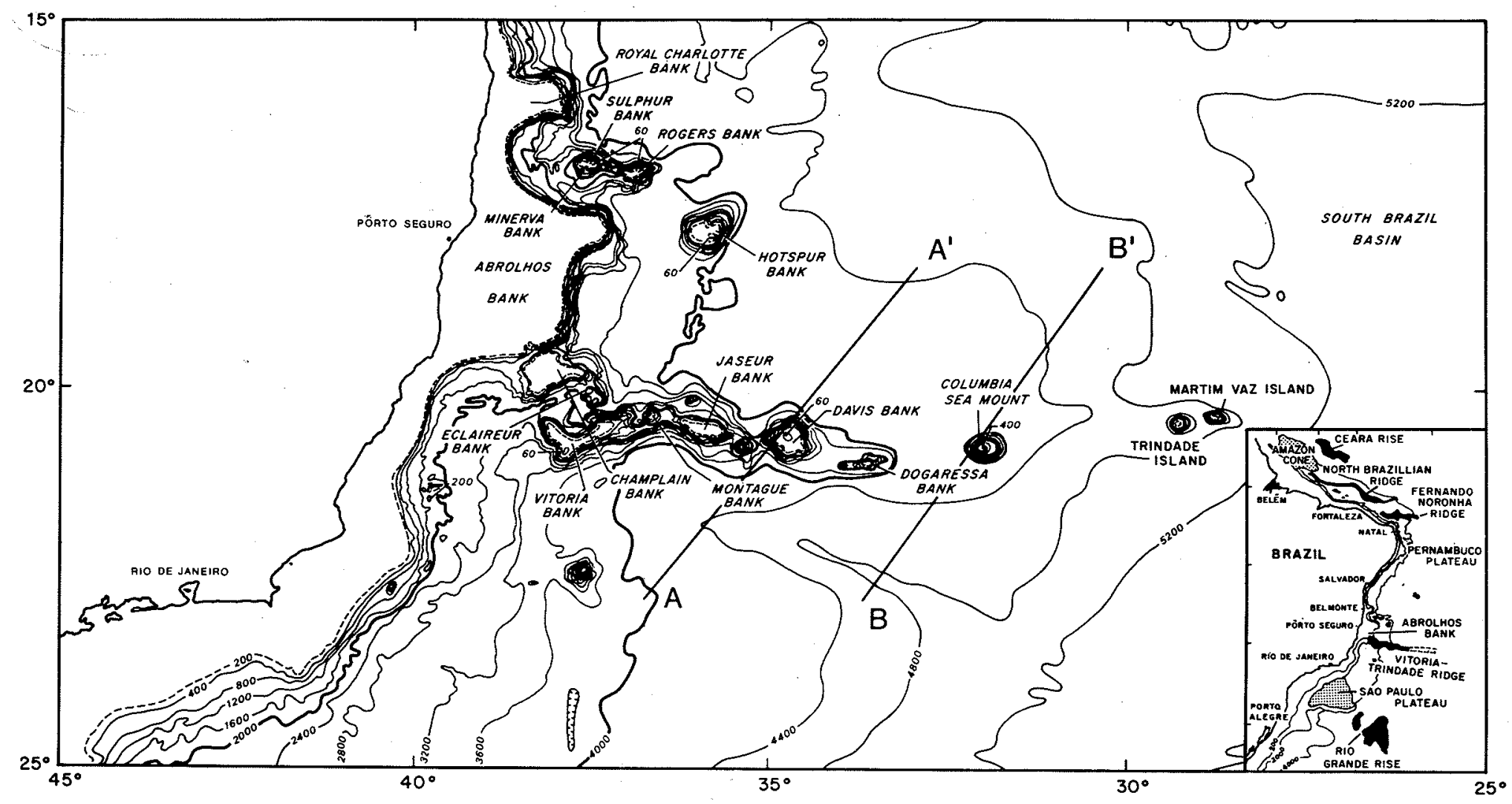

Figure 1 - Bathymetric map of the Vitoria-Trindade ridge, showing the location of the profiles analysed in this paper. Bathymetry in meters. Modified from Uchupi, 1971 


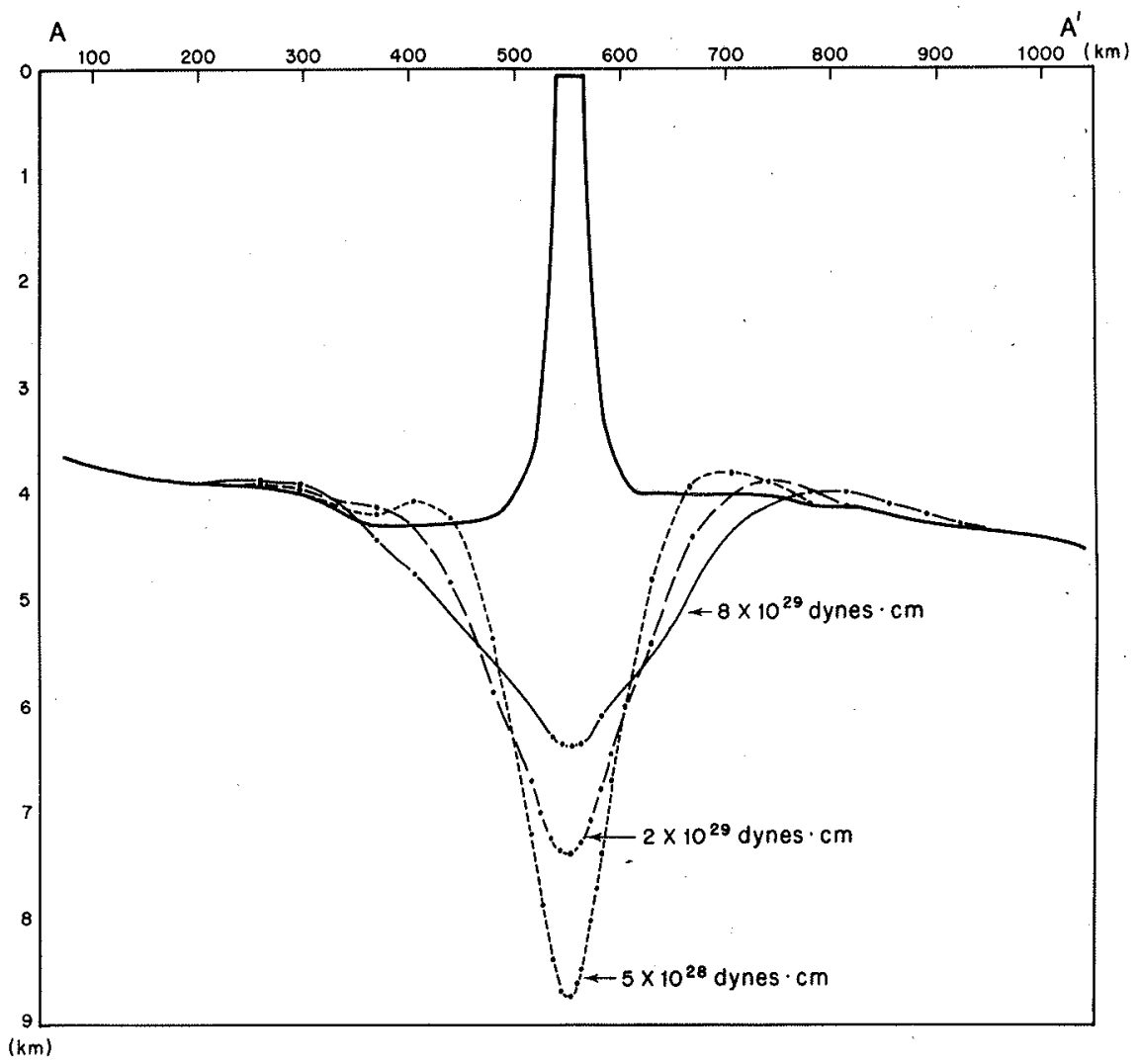

Figure 2 - Topography of Davis Bank guyot, and elastic deformations of the lithosphere for assumed values of flexural rigidities

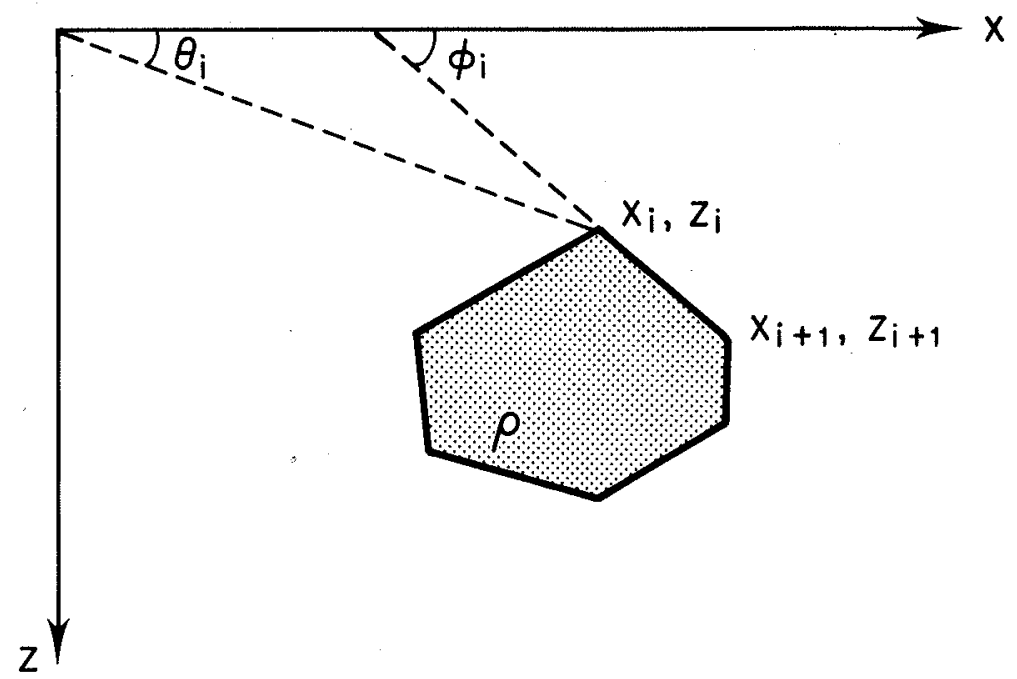

Figure 3 - Notation and coordinate system for the computation of the vertical gravitational attraction due to an $n$-sided polygon 

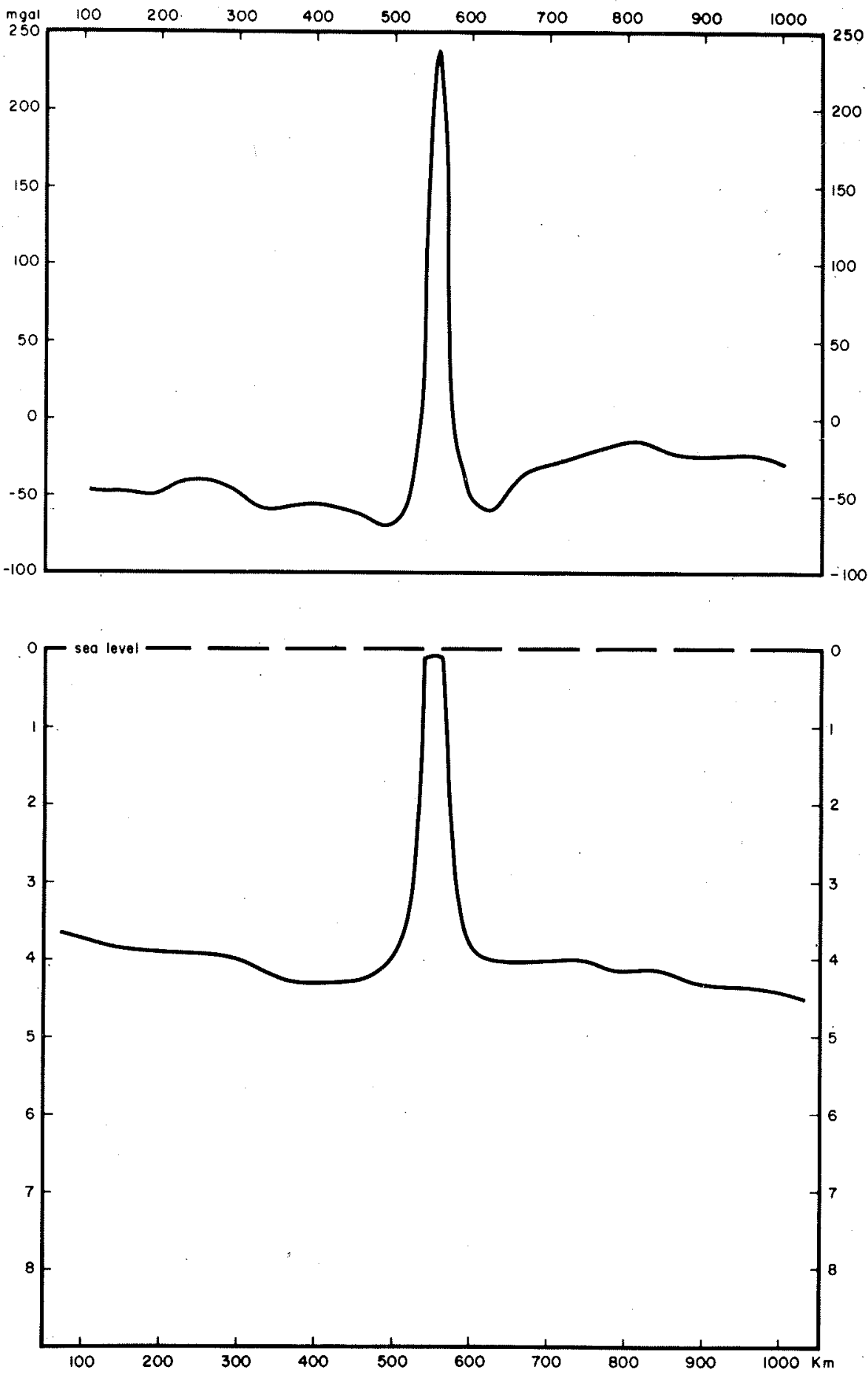

Figure 4a - Gravity and topographic profiles over the Davis Bank guyot (a) and Columbia seamount (b) 

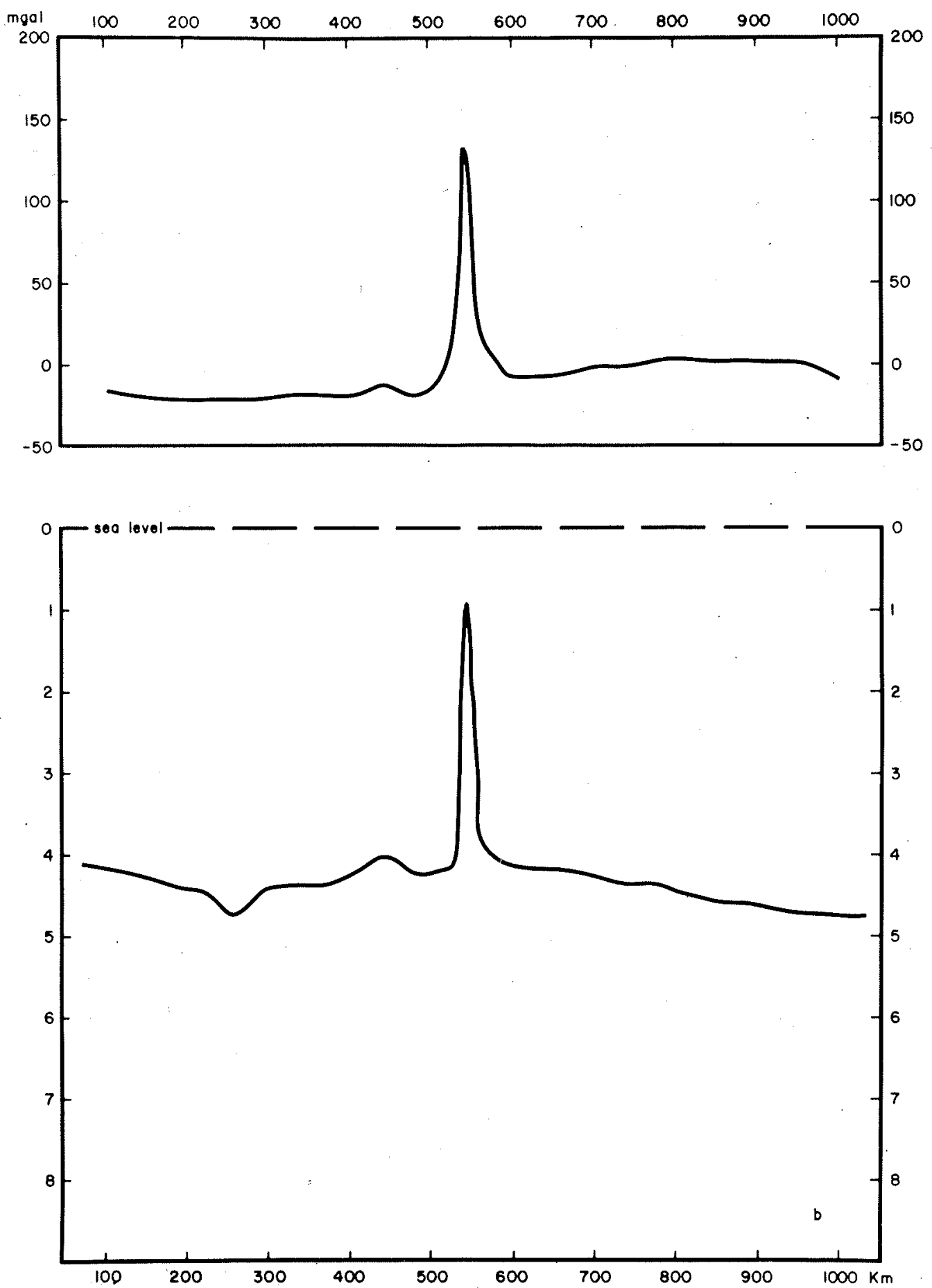

Figure 4b- 


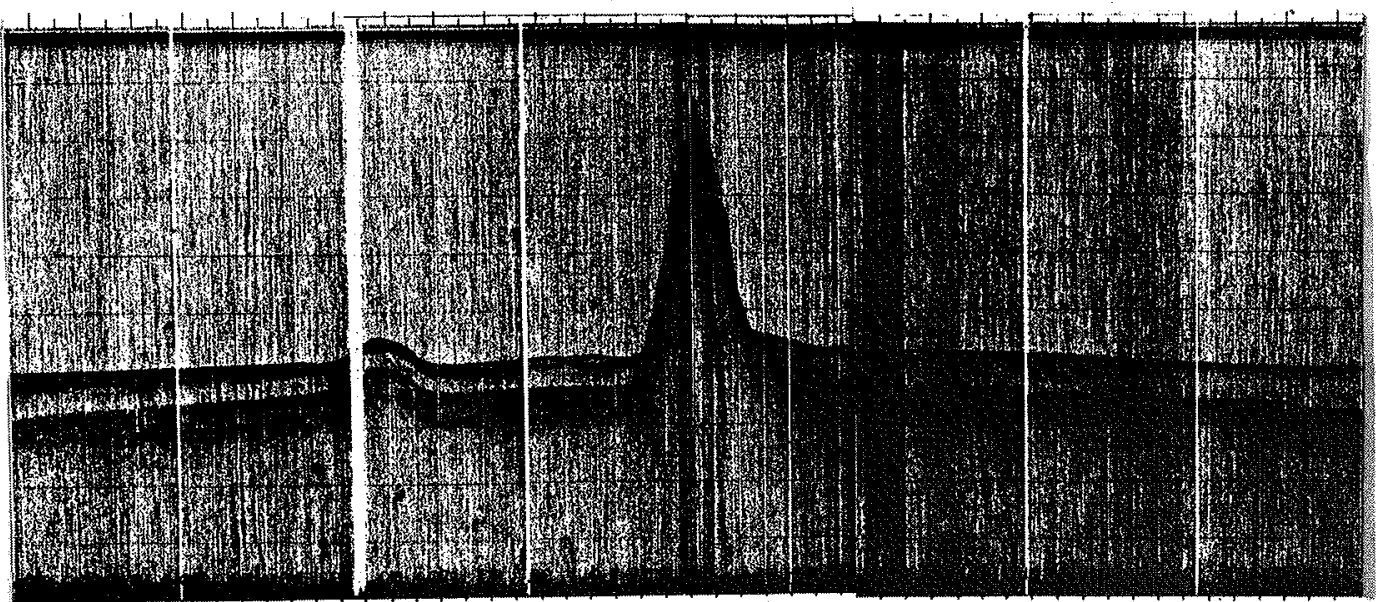

Figure 5 - Seismic reflections profile across the Columbia seamount showing a sediment accumulation of about $1 \mathrm{~km}$ overlying oceanic layer 2

CRUSTAL MODELS The structure derived for the ridge was based on matching the observed gravity anomaly with the vertical gravitational attraction generated from the computer models. In order to further constrain the models, the seismic reflection records were examined in order to correct for sediments overlying the oceanic basement (Fig. 5). Typical densities were $1.03 \mathrm{~g} / \mathrm{cm}^{3}$ for seawater, $2.2 \mathrm{~g} / \mathrm{cm}^{3}$ for sediments, $2.84 \mathrm{~g} / \mathrm{cm}^{3}$ for oceanic layer $2,2.9 \mathrm{~g} / \mathrm{cm}^{3}$ for layer 3 and $3.4 \mathrm{~g} / \mathrm{cm}^{3}$ for the upper mantle (Figs. $6 \mathrm{e} 7$ ).

CONCLUSIONS The Vitória-Trindade ridge is a volcanic feature associated with large amplitude free-air gravity anomalies. At the Davis Bank, the positive anomaly is $240 \mathrm{mgal}$ and is bordered by negative lobes which reach an amplitude of $-60 \mathrm{mgal}$.

The structural model is constrained by considering the lithosphere to be a thin and purely elastic plate. The value of the flexural rigidity of the lithosphere which best explains the amplitude and wavelength of the observed gravity anomalies is $2.10^{29}$ dynes-cm.

Acknowledgments This study was carried out at Rice University. One of us (R.F.) is supported by a research grant from Conselho Nacional de Desenvolvimento Científico e Tecnológico (CNPq) - Rio de Janeiro - Brazil. We thank Dr. L. L. Nettleton for discussing parts of the work, C. O. Bowin from Woods Hole Oceanographic Institution for providing access to the gravity computer library and $\mathrm{D}$. Meinert for the careful drafting of the illustrations. 

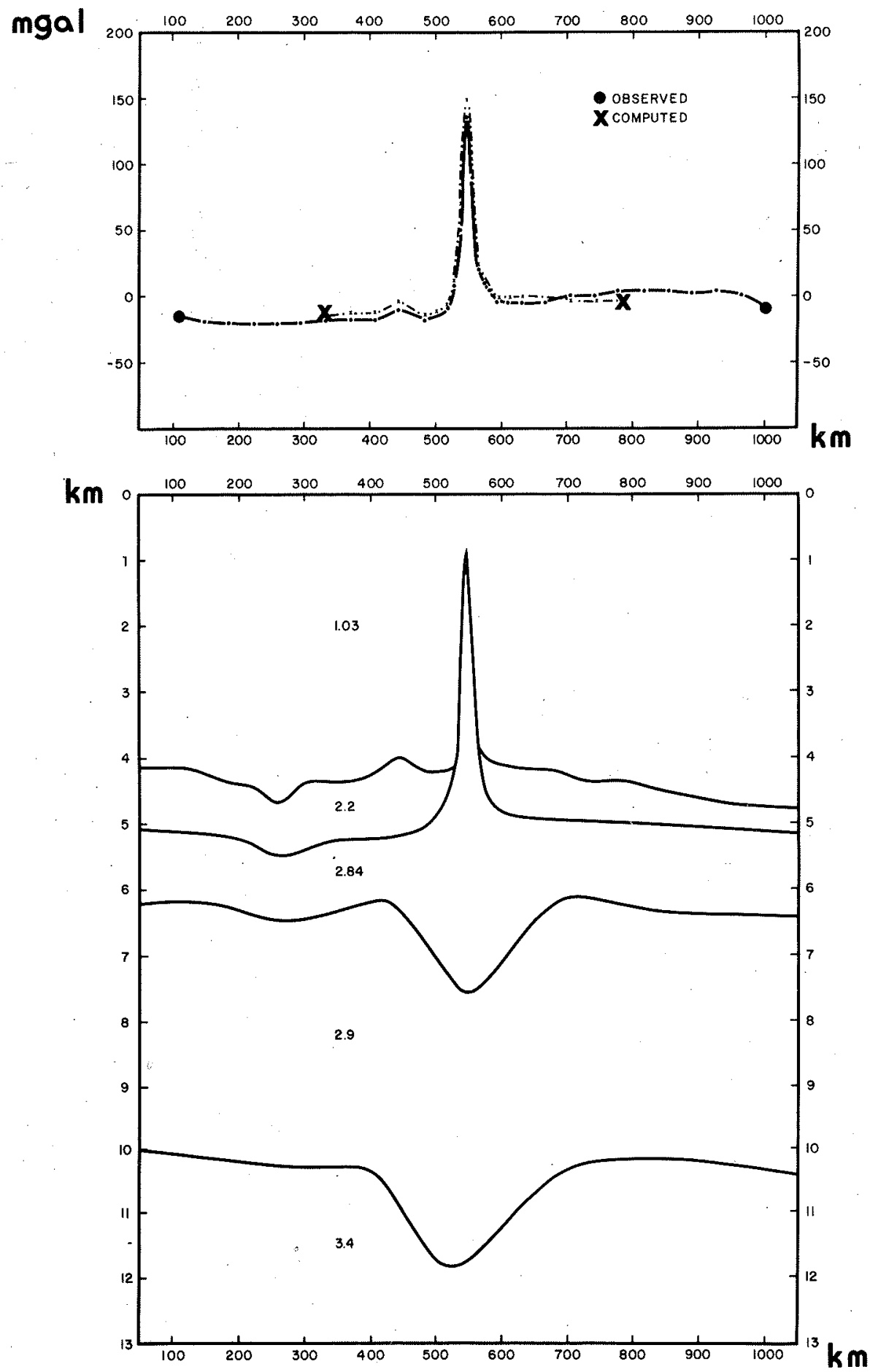

Figure 6 - Crustal structure beneath the guyot, and the correspondent gravitational effect of the assumed density model 

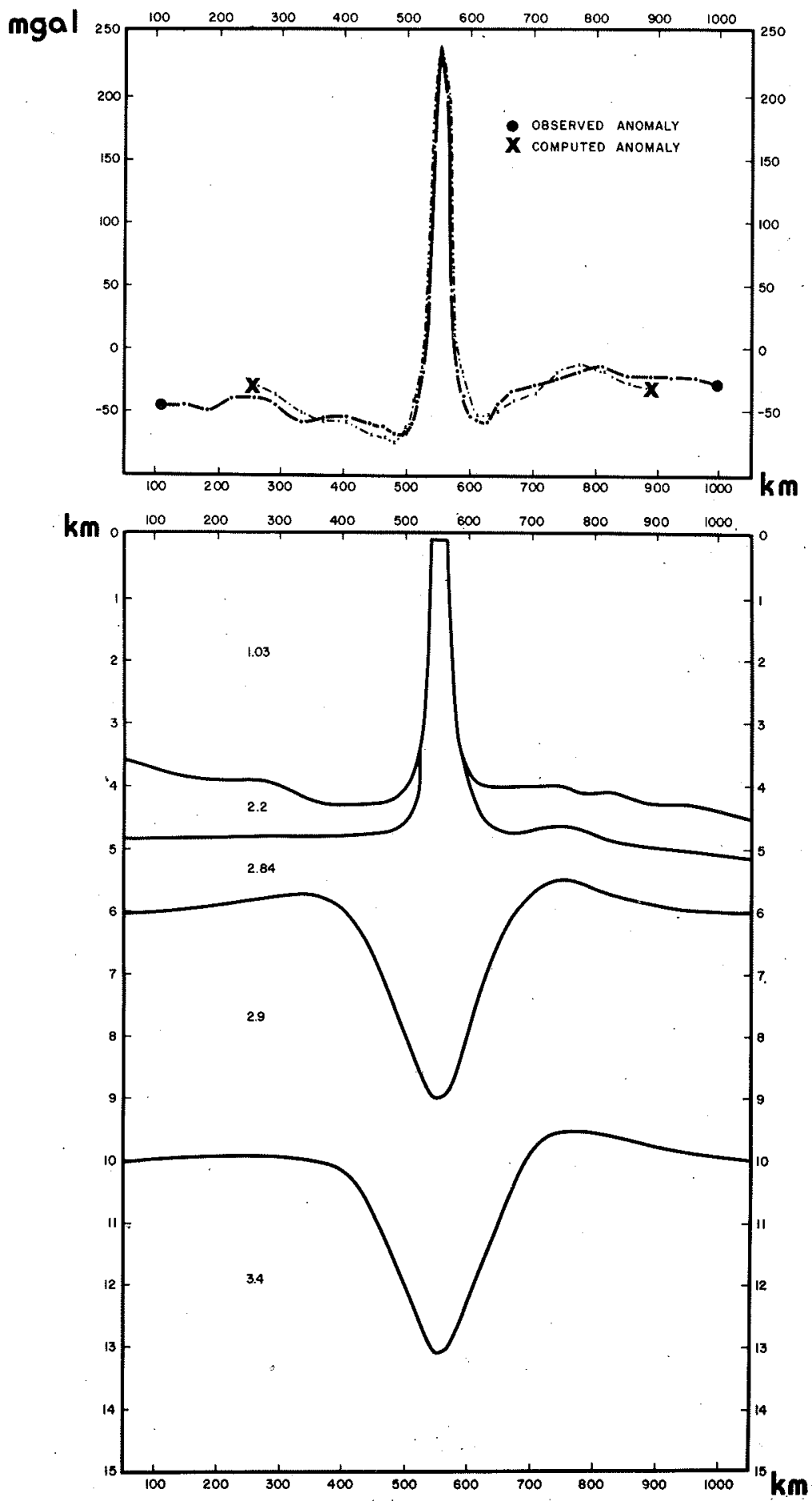

Figure 7 - Observed gravity anomaly, computed anomaly and model of deformed crust beneath the Columbia seamount. Peak value of computed anomaly is higher than the peak value of observed anomaly because profile crosses the flank of the seamount 


\section{APPENDIX}

We consider the lithosphere as being a thin elastic sheet, bending under a point load (Fig. I), in the absence of external horizontal forces. The vertical displacement of an elastic beam under these conditions is given by:

$E I \frac{d^{4} y}{d x^{4}}+\left(\rho_{m}-\rho_{c}\right) g y=q(x)$.

If the sheet is very long and loaded by a concentrated force (case of two-dimensional profiles crossing linear aseismic ridges in directions perpendicular to their trends), then $q(x)$ is reducible to $P \cdot \delta(x)$, and we may consider an infinite beam, because its deflections $y(x)$ are going to be very small for large values of $|x|$.

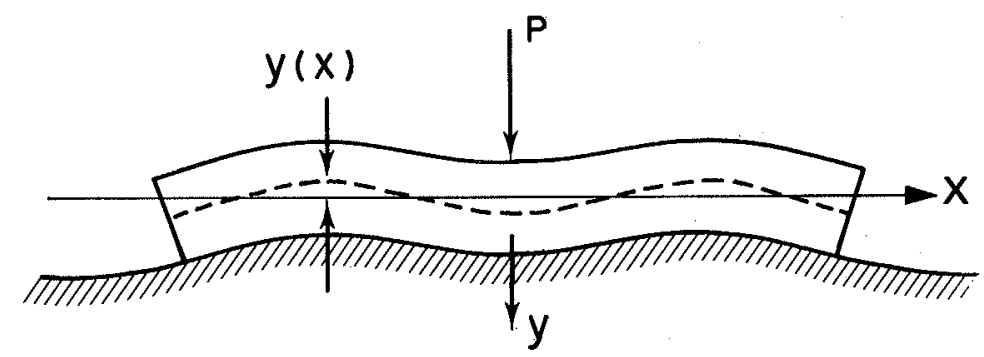

Figure I - Elastic deformation of a plate subjected to a point load

Using the Fourier transform method:

$F\left\{\frac{d^{4} y}{d x^{4}}\right\}=k^{4} Y(k) \quad$ where $F\{y\}=Y(k)$,

writing $\left(\rho_{m}-\rho_{c}\right) g=C$

$\left(E I k^{4}+C\right) Y(k)=Q(k) \quad$ with $Q(k)=F\{q(x)\}$

therefore,

$y(x)=F^{-1}\{Y(k)\}=\frac{1}{\sqrt{2 \pi}} \int_{-\infty}^{+\infty} \frac{Q(k) e^{-i k x}}{E I k^{4}+C} d k$

now taking $q(x)=P \cdot \delta(x)$ then $Q(k)=\frac{P}{\sqrt{2 \pi}}$, 
consequently

$y(x)=\frac{P}{2 \pi} \quad \int_{-\infty}^{+\infty} \frac{e^{-i k x}}{E I k^{4}+C} d k$

considering the definition of flexural parameter:

$\frac{\alpha^{4}}{4}=\frac{E I}{C} \quad$ making $\quad \alpha k=z$,

then,

$y(x)=\frac{P}{2 \pi c \alpha} \quad \int_{-\infty}^{+\infty} \frac{e^{-i\left(\frac{x}{\alpha}\right) z}}{\frac{z^{4}}{4}+\mathrm{I}} d z$,

changing variables again by $\frac{z^{4}}{4}=u^{4}$, we get:

$y(x)=\frac{P \sqrt{2}}{2 \pi c \alpha} \quad \int_{-\infty}^{+\infty} \frac{e^{-i\left(\frac{\alpha\left(\frac{\sqrt{2}}{\alpha}\right)}{u}\right.}}{u^{4}+1} d u$,

we need to calculate:

$I=\oint \quad \frac{e^{-i\left(\frac{a \sqrt{2}}{\alpha}\right\} u}}{u^{4}+1} d u$

Poles of the integrand are:

$e^{\frac{\pi}{4}}, e^{3 \pi}, e^{-4^{\pi}}, e^{--^{3 n}}$,

for the case $x<0$, we consider only the poles $e^{+^{\frac{\pi}{4}}}$ and $e^{-i^{3 m p}}$ (Fig. II).

Also by Cauchy's.theorem:

$I=2 \pi i\left[\operatorname{Res}\left(e^{\frac{\pi}{4}}\right)+\operatorname{Res}\left(e^{\frac{3 \pi}{4}}\right)\right]$, 
282

Revista Brasileira de Geociências Volume 8, 1978

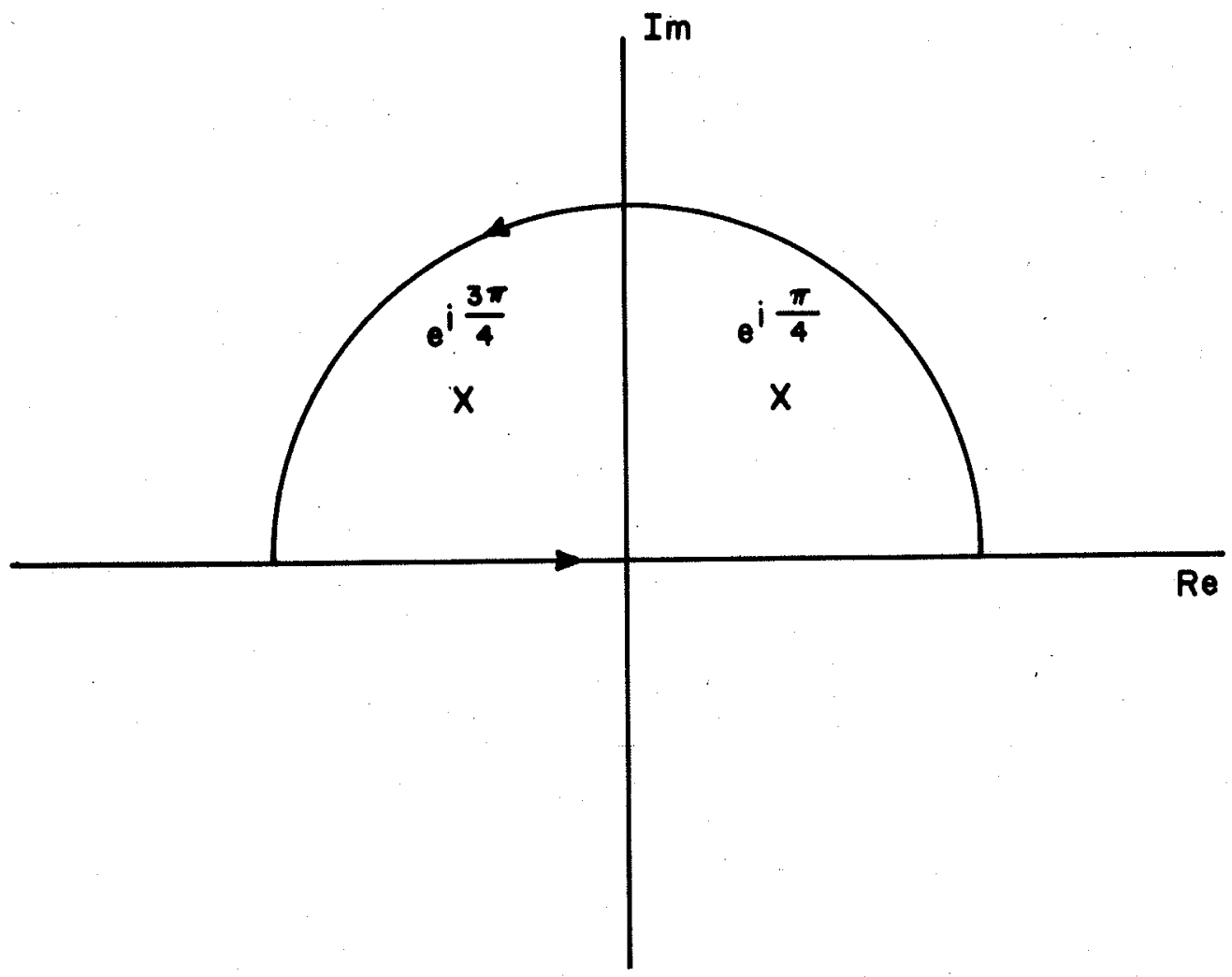

Figure II - Contour path for the integral $I$ in the case $x<0$. Poles $e^{t \frac{\pi}{4}}$ and $e^{i \frac{3 \pi}{4}}$

the calculation is straightforward and yields:

$y(x)=\frac{P}{2 \alpha c}\left(\cos \frac{x}{\alpha}-\sin \frac{x}{\alpha}\right) e^{x / \alpha}$,

for $x>0$ the calculation is similar (poles $\dot{e}^{-\mathrm{-}^{4}},{e^{-\mathrm{i}^{4}}}^{-\bar{\pi}}$ ) and gives:

$y(x)=\frac{P}{2 \alpha c}\left(\cos \frac{x}{\alpha}+\sin \frac{x}{\alpha}\right) e^{-x / \alpha}$,

combining these two expressions:

$y(x)=\frac{P}{2 \alpha c}\left(\cos \frac{|x|}{\alpha}+\sin \frac{|x|}{\alpha}\right) e^{-\frac{|x|}{\alpha}} \quad($ all $x)$. 


\section{REFERENCES}

ALMEIDA, F.F.M. de - 1965 - As ilhas oceânicas brasileiras e uma hipótese sobre a origem do Atlântico: Anais da Academia Brasileira de Ciências, 37: 141-145

CORDANI, U.G. - 1970 - Idade do vulcanismo no Oceano Atlântico Sul. Boletim do Instituto de Geociências e Astronomia da Universidade de São Paulo. 1: pp. 1-75

KOGAN, M.G. - 1976 - The Gravity Field over Oceanic Block Ridges. Izv. Earth Physic, 11: $32-43$

LANDAU, L.D. and LIPSCHITZ, Y.M. - 1969 - Theory of Elasticity, Course of Theoretical Physics, vol. 7, Pergamon Press

LE PICHON, S., FRANCHETEAU, J., and BONNIN, J. - 1973 - Plate Tectonics, Elsevier, New York, 300 pp.

LLIBOUTRY, L. - 1974 - Rheological properties of lithosphere: Tectonophysics, 23: 13-69

NADAI A. - 1963 - Theory of Flow and Fracture in Solids, vol. 2, 705 pp. McGraw-Hill, New York

PONTE, F.C. and ASMUS, H.E. - 1976 - The Brazilian Marginal Basins: current state of knowledge. Anais da Academia Brasileira de Ciências, 48 (suppl.): 215-240

TALWANI, M., WORZEL, J.L. and LANDISMAN, M. - 1959 - Rapid gravity computations for two-dimensional bodies with application to the Mendocino Submarine Fracture Zone. Journal of Geophysical Research, 64: 49-59

UCHUPI, E. - 1971 - Bathymetric Atlas of the Atlantic, Caribbean and Gulf of Mexico. Woods Hole Oceanographic Institution. Ref. No. 71-72 (unpublished)

WALCOTT, R.I. - 1970a - Flexural rigidity, thickness and viscosity of the lithosphere. Journal of Geophysical Research, 75: 3941-3954

WALCOTT, R.I. - 1970b - Flexure of the lithosphere at Hawaii. Tectonophysics, 9: 435-446

WATTS, A.B. and COCHRAN, J.R. - 1974 - Gravity anomalies and flexure of the lithosphere along the Hawaiian-Emperor seamount chain. Geophysical Journal of the Royal Astronomical Society. 38: 119-141

WATTS, A.B., COCHRAN, J.R. and SELZER, G. - 1975 - Gravity anomalies and flexure of the lithosphere. A three-dimensional study of the Great Meteor Seamount, Northeast Atlantic. Journal of Geophysical Research, 80: 1391-1398 